\title{
DCAF1 wt Allele
}

National Cancer Institute

\section{Source}

National Cancer Institute. DCAF1 wt Allele. NCI Thesaurus. Code C107421.

Human DCAF1 wild-type allele is located in the vicinity of 3p21.2 and is approximately 110 $\mathrm{kb}$ in length. This allele, which encodes DDB1- and CUL4-associated factor 1 protein, is involved in both substrate recognition by the E3 ubiquitin-protein ligase complex and serine-threonine phosphorylation. 